\title{
Comentário: "o futuro do livro na avaliação dos programas de pós-graduação"
}

\author{
Commentary
}

Comentario

Rita Barradas Barata ${ }^{1}$

As reflexões do professor José Castilho Marques Neto acerca do futuro do livro provocam outras tantas idéias sobre aspectos relacionados ao papel do livro na difusão dos conhecimentos científicos, artísticos e filosóficos e sua relação com os processos de formação de docentes e pesquisadores.

O primeiro aspecto que merece destaque é a análise das diferentes tradições existentes nos diversos domínios de produção de saberes, relacionadas com a produção, difusão e apropriação destes conhecimentos. Assim, no vasto campo das ciências existem diferentes tradições. Em todas elas estão presentes as várias formas de divulgação do conhecimento produzido: apresentações em eventos científicos, artigos publicados em periódicos, capítulos de livros em coletâneas e livros, variando apenas a relevância e a precedência que se confere a cada uma destas formas. Por exemplo, no campo da antropologia, geralmente os resultados de extensas pesquisas de campo são divulgados sob a forma livro, ainda que parte dos mesmos possa ser apresentada como artigos em periódicos. Já no âmbito da epidemiologia é mais freqüente que os resultados de extensas pesquisas de campo sejam publicados em vários artigos, em periódicos, não gerando necessariamente a publicação de livros.

Um outro aspecto relativo aos livros como suporte para a divulgação de conhecimentos remete a uma reflexão necessária na contemporaneidade: a relação entre processos reflexivos e consumo imediato de resultados. A forma livro sem dúvida se presta melhor à divulgação de teorias, elaborações conceituais, formulação de metodologias, apresentação de técnicas de análise e a forma artigo se presta mais ao registro de resultados empíricos imediatos, cuja perenidade será menor em virtude dos avanços constantes, mas, principalmente, da avalanche de pesquisas existentes.

Outro aspecto de extrema importância destacado pelo professor Castilho é o papel que a revisão por pares têm no que respeita à qualidade da produção. Esta depende da correta aplicação do método, mas também do julgamento interpares, ou seja, a verdade é construída no interior da comunidade da qual o cientista faz parte. Sem o julgamento pelos pares não há garantia, para os leitores, de que aqueles saberes passaram pelo crivo da comunidade de cientistas que compartilham interesses semelhantes.

${ }^{1}$ Professora Adjunta, Departamento de Medicina Social, Faculdade de Ciências Mèdicas Santa Casa, São Paulo. <rita.barata@fcmscsp.edu.br> 


\section{DEBATES}

Entretanto, como bem salientou o professor, a publicação de livros é movida por dois vetores fundamentais: a relevância e qualidade do conteúdo que se pretende disseminar e os interesses comerciais ou a viabilidade econômica da publicação. Evidentemente, existem editoras como as universitárias que não têm interesse no lucro em si, mas que dependem do sucesso de suas vendas para a própria manutenção de suas atividades. Nesse sentido, autores de importantes produções científicas, filosóficas ou artísticas poderiam ter dificuldade para publicar seus trabalhos não por razões associadas à qualidade de sua produção, mas, sim, pelo público relativamente reduzido que as mesmas teriam.

Tendo em vista a adoção de critérios quantitativos e qualitativos de produtividade para avaliar os docentes e pesquisadores bem como os programas de formação dos quais participam, esse impedimento de ordem financeira introduz um viés difícil de corrigir.

A divulgação por meios eletrônicos, que reduzem em parte os custos de impressão e de distribuição, aparece como uma das saídas para o impasse. Entretanto, como lembra o Professor Castilho, para a garantia de qualidade seria bom que mesmo os livros eletrônicos pudessem ser submetidos ao julgamento entre pares antes de serem divulgados. Sua sugestão é que as editoras poderiam desempenhar este papel.

Do ponto de vista da divulgação científica, filosófica e artística, além do aspecto de qualidade acima mencionado, seria importante que o texto editado apresentasse as características necessárias para indexação pois, caso contrário, ainda que disponível em meio eletrônico, o acesso a ele seria dificultado pela impossibilidade de ser captado pelos mecanismos de busca bibliográfica mais formais.

A discussão em torno da sobrevivência do livro poderá propiciar o início de uma reflexão urgente com relação aos critérios de concepção, realização e avaliação dos cursos de pós-graduação no Brasil. Muitas vezes perdemos de vista o objetivo principal de nosso trabalho, deixando-nos arrastar pelas necessidades pragmáticas de apresentar desempenho satisfatório perante determinados sistemas de avaliação, parecendo ignorar que todo sistema de avaliação contém, em si, valores implícitos.

Seria extremamente útil à nossa pós-graduação que docentes e pesquisadores refletissem sobre a real importância e o sentido de formar novos pesquisadores e produzir novos saberes, para então definir qual a forma mais apropriada de avaliar a qualidade do que está sendo feito.

As reflexões do Professor Castilho oferecem-nos a oportunidade rara para nos questionarmos: para que organizamos cursos de mestrado e doutorado? Que características devem ter esta formação? Quais são as melhores formas de divulgação dos saberes produzidos? Como avaliar as diferentes formas de produção? Como respeitar as diferentes tradições em campos multidisciplinares?

Nós todos que fomos formados na tradição da leitura como forma privilegiada de se apropriar do conhecimento sobre o mundo cremos, certamente, na permanência do livro, seja em versão impressa, seja em versão eletrônica, como suporte imprescindível para a veiculação de conhecimentos considerados válidos e relevantes. Coerentemente com esta crença devemos valorizar corretamente a elaboração e editoração de livros, dando aos diferentes meios de produção/divulgação de saberes o peso adequado na avaliação.
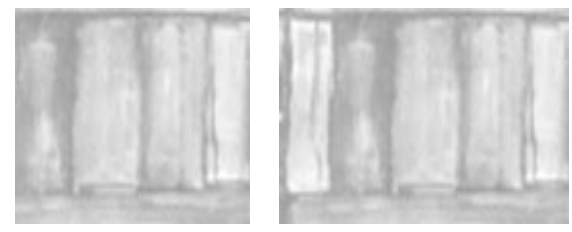